\title{
Apresiasi Lintas Genre Musik Indonesia Melalui Synchronize Festival
}

\author{
Dadang Dwi Setiyan \\ ${ }^{1}$ Prodi Pendidikan Seni Pertunjukan, Universitas Sultan Ageng Tirtayasa, Kota Serang, Banten, Indonesia \\ ${ }^{(*)} \bowtie$ (e-mail) dadang.vivaldi@untirta.ac.id ${ }^{1}$
}

\begin{abstract}
Abstrak
Synchronize Festival merupakan festival musik multi-genre tahunan berskala nasional yang mengundang puluhan ribu audiens untuk merayakan keberagaman jenis musik hidup di lima panggung selama tiga hari, tiga malam, menikmati suguhan 100-an pertunjukan terkurasi dari artis-artis terbaik tanah air yang datang dari dekade 1970-an, 1980-an, 1990-an hingga 2000-an. Melihat popularitas Synchronize Festival yang digandrungi oleh penikmat musik lintas genre di Indonesia, maka penelitian ini bertujuan untuk memberikan informasi deskriptif tentang kontribusi yang diberikan Synchronize Festival terhadap pendidikan apresiasi musik lintas genre musik. Hasil penelitan menunjukan bahwa, Synchronize Festival dapat meng-capture industri musik tanah air dan berupaya memfasilitasi seluruh genre musik, termasuk musik-musik yang dianggap "norak". Salah satu karakter Synchronize Festival yaitu mengundang musik-musik yang kesannya sudah tertinggal kemudian dikenalkan kembali kepada penonton, yang pada akhirnya mengedukasi penonton yang sebelumnya tidak mengetahui menjadi banyak pengetahuan baru yang didapat setelah hadir dalam Synchronize Festival.
\end{abstract}

Kata kunci: synchronize festival, festival musik, apresiasi musik

\begin{abstract}
Synchronize Festival is an annual multi-genre music festival on a national scale that invites tens of thousands of audiences to celebrate the diversity of live music on five stages for three days, three nights, enjoying 100s of curated performances from the country's best artists from decades. 1970s, 1980s, 1990s to 2000s. Seeing the popularity of Synchronize Festival which is loved by music lovers across genres in Indonesia, this study aims to provide descriptive information about the contribution that Synchronize Festival makes to music appreciation education across music genres. The results of the research show that Synchronize Festival can capture the country's music industry and try to facilitate all genres of music, including music that is considered "tacky". One of the characteristics of the Synchronize Festival is to invite music whose impression has been left behind and then reintroduced to the audience, which in the end educates the audience who previously did not know into a lot of new knowledge gained after attending the Synchronize Festival.
\end{abstract}

Keywords: synchronize festival, music festival, music appreciation.

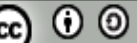

This work is licensed under a Creative Commons Attribution-ShareAlike 4.0 International License. Copyright (C) 2021 Dadang Dwi Setiyan

\section{Proses Artikel}

Diterima 02-04-2021; Revisi 03-05-2021; Terbit Online 24-06-2021 


\section{Pendahuluan}

Pendidikan musik merupakan pembahasan yang spesifik. Pendidikan pada umumnya juga tidak hanya berpangku pada persoalan-persoalan nilai fisik yang tampak luar saja, namun pada nilai-nilai intrinsik. Setiap individu bertanggungjawab untuk mampu mengambil keputusan secara mandiri demi meningkatkan kualitas hidup. Maka, pendidikan juga merupakan upaya pertahanan (Mark \& Madura, 2013).

Berbagai literatur menyebutkan, bahwa pendidikan musik tidak dominan mengasah keterampilan teknis, tidak seperti dalam disiplin pertunjukan musik (music performance). Namun, keterampilan teknis yang memadai akan dapat menjadi jembatan untuk menelusuri makna-makna yang lebih dalam lagi. Pendidik musik yang tidak memiliki kejelian atau kecermatan dalam mengamati fakta musik juga akan berakibat sulitnya memahami pesanpesan implisit yang tersampaikan melalui musik tersebut (Septiyan, 2019).

Metode pendidikan musik atas hubungan antara manusia dan musik menurut Swanwick, "They are then two crucial educational points to be kept in mind as we consider the modes of relationship between people and music. The first of these is that teachers should be concerned with the promotion of specific musical experiences of one kind or another. The second is that students should take up different rolse in a variety of musical environments. People will find their individual paths into particular areas of music." (Swanwick, 2003, p. 24)

Beberapa poin penting di atas adalah kepedulian guru, pengalaman musik yang spesifik (yang dicontohkan guru), murid yang memiliki peran (tidak pasif), dan lingkungan musik. Lingkungan musik menurut Swanwick, diartikan sebagai keragaman yang terikat dengan lingkungan di sekitarnya serta latarbelakang budaya, itu pun fleksibel sifatnya. Bagi Swanwick, setiap orang dapat dengan mudah menyesuaikan kebiasaan bermusik dalam berbagai kondisi lingkungan untuk memperkaya wawasan musik.

Synchronize Festival di Jakarta merupakan festival musik multi-genre tahunan berskala nasional yang mengundang puluhan ribu pengunjung untuk merayakan keberagaman jenis musik hidup di lima panggung selama tiga hari, tiga malam, menikmati suguhan 100-an pertunjukan terkurasi dari artis-artis terbaik tanah air yang datang dari dekade 1970-an, 1980an, 1990-an hingga 2000-an.

Seluruh genre musik populer ada di dalam Synchronize Festival, mulai dari genre pop, $R \& B$, rock \& roll, blues, folk, jazz, punk, heavy metal, hiphop, reggae, ska, atau sub-genre hardcore, metalcore, death metal, grindcore, industrial rock, new wave, indie pop, alternative rock/grunge, bossanova, komedi, bahkan hingga dangdut pun hadir dalam pergelaran Synchronize Festival. Selain dapat menikmati ratusan pertunjukan musik, Synchronize Festival juga menyuguhkan berbagai pengalaman terkurasi lainnya bagi para penonton di antaranya adalah Outdoor Cinema, Art \& Merch Market, Records Fair hingga F\&B Festival.

Beberapa penelitian yang terdahulu terkait dengan Synchronize Festival memberikan sebuah kontribusi dalam kebaruan penelitian ini. Beberapa di antaranya mengatakan bahwa Synchronize Festival merupakan festival musik berskala internasional dengan berbagai jenis genre dalam satu kegiatan dan dilakukan secara berkala setiap tahunnya yang selalu ramai didatangi pengunjungnya yang mencapai puluhan ribu pengunjung. Synchronize Festival mampu mengadakan lebih dari 100 pertunjukan dari penyanyi serta band tanah air dari berbagai dekade. (Purnama, 2020) 
Synchronize Festival membawa keberagaman fenomena musik untuk memberikan edukasi penonton milenial dengan legenda musik Indonesia. Sebagai contoh fenomena Didi Kempot, era musik Emo Indonesia di awal tahun 2000 juga telah dihidupkan kembali dalam festival musik ini. Direktur program Synchronize Festival, Kiki Ucup, mengatakan Synchronize Festival merupakan festival musik Indonesia lintas genre yang menghadirkan lebih dari 100 musisi untuk tampil dan menyemarakkan ragam musik tanah air yang memberikan kontribusi pendidikan tentang musik di Indonesia melalui sebuah festival (Anderton, 2011; Hakim, 2015; Packer \& Ballantyne, 2011; Sinaga, 2020; Stone, 2009).

Melihat popularitas Synchronize Festival yang digandrungi oleh penikmat musik lintas genre di Indonesia, maka fokus dari penelitian ini terkait dengan kontribusi yang diberikan Synchronize Festival terhadap pendidikan apresiasi musik lintas genre musik.

\section{Metode}

Penelitian ini menggunakan metode kualitatif. Lokasi penelitian dilakukan di Jakarta. Objek penelitian ini adalah pertunjukan musik Synchronize Festival. Data dalam penelitian ini bersumber dari informasi yang terdiri dari media massa, internet, audience dalam Synchronize Festival dan pemerhati musik Indonesia. Teknik pengumpulan data yang dilakukan adalah observasi, wawancara (interview) dan dokumentasi. Hal yang diobservasi adalah pertunjukan musik Synchronize Festival di Jakarta. Wawancara dilakukan kepada beberapa informan, di antaranya adalah audience dan pemerhati musik Indonesia. Wawancara yang digunakan adalah wawancara terstruktur yaitu peneliti membawa pertanyaan yang merupakan garis besar tentang hal yang diteliti.

\section{Hasil}

\section{Synchronize Festival}

Pertunjukan musik live adalah sebuah pertunjukan musik yang mensyaratkan kehadiran seniman (musisi) dengan penonton bersama di tempat yang sama dan disaat yang bersamaan (Doğantan-Dack, 2012). Musisi menampilkan pertunjukan musik untuk dapat dinikmati oleh penontonnya dengan baik, agar pesan musik yang disampaikan oleh musisi dapat diterima dengan baik oleh penonton maka diperlukan kondisi ruang yang layak dilihat dari segi akustik, dan juga peralatan penunjang pertunjukan seperti tata panggung, sound system, dan tata lighting yang layak dan memadai. Jika elemen-elemen tersebut tidak terpenuhi dengan baik maka pertunjukan dapat dikatakan tidak berhasil karena penonton merasa tidak dapat menikmati pertunjukan (Yngvar, 2018).

Synchronize Festival selalu membawa keberagaman fenomena di industri musik Indonesia. Festival musik ini mengedukasi penonton, khususnya generasi milenial terhadap legenda musik, fenomena campursari, dangdut, nasyida ria, hingga era musik Emo Indonesia di awal tahun 2000. Selain itu juga terdapat beragam genre musik yang diusung oleh musisi Indonesia melalui karya nya seperti, pop, R\&B, rock \& roll, blues, folk, jazz, punk, heavy metal, hiphop, reggae, ska, atau sub-genre hardcore, metalcore, death metal, grindcore, industrial rock, new wave, indie pop, alternative rock/grunge, bossanova, dan komedi.

Pengalaman yang dihadirkan dalam Synchronize Festival dapat langsung dirasakan terkait dengan wawasan musik melalui apresiasi langsung kepada penonton. Maka aspek auditif, pendengaran, menjadi bagian yang tidak kalah penting. Listening (mendengarkan), 
adalah pintu masuk utama dari semua aktivitas musik, tidak hanya dalam konteks mendengarkan rekaman musik, namun menikmati pertunjukan musik secara langsung.

Pertunjukan musik seperti halnya Synchronize Festival mengandung sense of music, dan ada sense of performance. Dala kaitannya dengan pertunjukan musik, menurut Swanwick dalam (Setiawan, 2017, p.52), musik akan sepenuhnya hadir. Dibutuhkan siasat lain, dan pertunjukan itu juga bukan menjadi sebuah goal, apalagi demi atraksi atau gengsi, melainkan sebagai sarana. Pertunjukan musik adalah sarana komunikasi yang menghubungkan manusia (individu), musik itu sendiri, dan antar manusia (sosial). Akan ada proses re-presentasi terusmenerus dari aktivitas pertunjukan yang selalu berbeda dalam situasi dan kondisi. Musik harus dipertunjukkan meskipun dalam situasi se-informal apapun, supaya peserta didik dapat selalu mengevaluasi kemampuannya terutama dalam menyampaikan pesan implisit kepada orang lain. Bukan gagal atau berhasil, melainkan proses itu sendiri.

Synchronize Festival selalu mendobrak segala konvensi festival musik lokal pada umumnya, dari mengandalkan musisi dalam negeri hingga menghadirkan kembali nostalgia ke hadapan penonton. Festival musik ini menciptakan euforia tersendiri di tengah anak-anak muda. Synchronize Festival memberikan pengalaman yang mungkin akan jarang dijumpai di kemudian hari, yaitu apresiasi pertunjukan musik dari Rhoma Irama hingga Nasida Ria di acara musik yang berbasis anak muda.

Hadirnya Synchronize Festival dapat meng-capture industri musik tanah air, artinya musik dalam negeri secara keseluruhan. Synchronize Festival berupaya memfasilitasi seluruh genre musik, termasuk musik-musik yang dianggap "norak", hal demikian justru menjadikan semacam karakter dari Synchronize Festival, yaitu mengundang musik-musik yang kesannya sudah seperti mitos kemudian dikenalkan kembali kepada penonton, yang pada akhirnya mengedukasi penonton yang sebelumnya tidak mengetahui menjadi banyak pengetahuan baru yang didapat setelah hadir dalam Synchronize Festival.

\section{Pembahasan}

\section{Peran Synchronize Festival Dalam Pendidikan Apresiasi Lintas Genre Musik Indonesia}

Pendidikan musik yang dilakukan sekolah saat ini, seringkali hanya bersumber dari buku-buku teori, sedikit sekali sekolah yang memfasilitasi murid-muridnya untuk bereksplorasi dan berapresiasi dalam proses pembelajarannya. Selain karena fasilitas sekolah yang tidak memadai untuk memutar video ataupun audio dengan kualitas yang baik, sarana dan fasilitas untuk siswa melakukan apresiasi dengan melakukan kunjungan ke pertunjukan seni musik pun menjadi terbentur karena jarangnya sebuah acara musik yang mengemas acaranya secara khusus dan menyeluruh dengan memasukkan aspek pendidikan ke dalam materi acaranya.

Aktivitas fisik dan cita rasa keindahan itu tertuang dalam kegiatan berekpresi, berekplorasi, berapresiasi berkreasi melalui bahasa rupa, bunyi, gerak dan peran yang masing-masing mencakup materi sesuai dengan bidang seni dan aktivitas dalam gagasangagasan seni, keterampilan berkarya serta apresiasi dengan memperhatikan konteks sosial budaya masyarakat. Pembelajaran seni di sekolah umum pada dasarnya diarahkan untuk menumbuhkan kepekaan rasa estetik dan artistik sehingga terbentuk sikap kritis, apresiatif dan kreatif pada diri siswa secara menyeluruh. Sikap ini hanya mungkin tumbuh jika dilakukan 
serangkaian proses kegiatan pengalaman, penilaian, serta penumbuhan rasa memiliki melalui keterlibatan siswa dalam segala aktivitas seni di dalam kelas atau di luar kelas (Tarsa, 2016).

Synchronize Festival setiap tahunnya selalu menghadirkan musisi-musisi lawas dalam rentang tahun yang jelas. Contohnya, musisi-musisi di era 1960-an atau 1970-an, seperti Chrisye. Mungkin kebanyakan orang sudah mengenal siapa itu Chrisye, namun belum tentu dengan anak-anak muda milenial sekarang. Inilah yang kemudian dijadikan kontribusi Synchronize Festival dalam mengedukasi kepada penonton tentang apa yang terjadi dalam industri musik lokal (Barrett \& Bond, 2015; Finney, 2002).

Tiket yang dijual oleh Synchronize Festival pun cukup murah, dengan tujuan untuk mendatangkan banyak penonton. Tiket Synchronize Festival tergolong mahal untuk pasar penonton yang pada umumnya diisi oleh anak-anak SMP, SMA, sampai mahasiswa. Namun Synchronize Festival dalam membangun vibes nya cukup baik. Ketika penonton Synchronize Festival musik itu pulang membawa hal yang positif, tentunya menjadi bekal untuk mengapresiasi kembali di tahun berikutnya. Salah satunya adalah alur pengisi acara. Synchronize Festival memberikan mood penonton menjadi happy ending.

Festival musik bukan ajang berkumpulnya band-band besar semata. Banyak nama "besar" bukan menjadi jaminan bahwa festival tersebut bagus. Festival musik yang terpenting adalah harus dapat menjadi wadah maupun ruang untuk pendidikan musik, selebrasi, dan tidak hanya melulu mengikuti permintaan pasar.

Suksesnya sebuah pertunjukan musik tidak pernah terlepas dari ide dan konsep pemikiran sebuah manajemen organisasi pertunjukan yang sudah profesional dan bekerja secara ahli di bidangnya. Sumber daya manusia merupakan faktor dominan dalam kegiatan produksi maupun daya saing, karena berperan sebagai pilar penyangga dan penggerak roda kegiatan organisasi apapun untuk berkembang dan maju. Sehingga sangat kecil kemungkinannya untuk sebuah acara menjadi sukses jika dikemas dan dikelola oleh sumber daya manusia yang tidak profesional.

Keunikan dalam suksesnya Synchronize Festival adalah keseluruhan pimpinan Synchronize Festival juga individu yang memang berkompeten dalam bidang musik. Penggagasnya adalah David Karto dari Demajors dan Muhammad Riza dari Dyandra Promosindo. Demajors merupakan salah satu indie label yang ada di Indonesia yang konsisten merilis album-album dari band atau musisi non-mainstream, yang didistribusikan melalui jalur industri musik mainstream. Demajors sebagai indie label tetap mempertahankan konsistensinya untuk memproduksi produk-produk musik non-mainstream, dengan jalur pemasaran produk ke industri musik mainstream. Demajors tidak membatasi pemasaran yang dilakukan untuk memproduksi musik non-mainstreamnya. Demajors sebagai indie label mengembangkan jaringan produksi musik non-mainstreamnya pada industri musik mainstream yang mendominasi pasar (Demajors News, 2020b). Kemudian Dyandra Promosindo merupakan induk perusahaan dari unit bisnis event organizer dalam PT. Dyandra Media International, Tbk. Dimana Dyandra Promosindo fokus pada bidang niaga serta retail di luar bidang IT, komputer, dan otomotif. Memiliki pengalaman dalam bidang event organizer selama lebih dari 20 tahun. (Rahmania, 2015, p.12)

Synchronize Festival di masa pandemi Covid-19, tepatnya di tahun 2020, tetap menggelar pertunjukan rutinnya, namun digelar di stasiun televisi. Tema yang diusung adalah "Selebrasi bersama Televisi", dengan tujuan penyelenggara ingin Synchronize Festival 2020 dapat lebih menjangkau pecinta musik di seluruh Indonesia di tengah keterbatasan akibat 
pandemi virus Covid-19. Selaras dengan jargon Synchronize Festival yaitu "A Festival for Everyone", kehadiran di televisi adalah terobosan baru bagi sebuah festival yang dapat menjangkau banyak pemirsa potensial di seluruh Indonesia dan tentunya dinikmati gratis oleh siapapun.

Menurut David Karto, pihak Synchcronize Festival tetap ingin memberikan sumbangsih hiburan agar dapat diapresiasi lebih luas bagi banyak orang dengan menghindari resiko penyebaran Covid-19. Ide dasarnya adalah tetap menjaga sustainable dan kewarasan semua pelaku dan apresiator musik. Bagaimana caranya tetap bisa menjaga eksistensi sektor musik dalam masa pandemi (Demajors News, 2020a).

Musik tidak lebih dari sekadar fanatisme, selalu mengagungkan jargon akademis demi kepentingan kelompok tertentu. Bahkan muncul pula gerakan-gerakan sepihak yang mengatasnamakan musik demi kepentingan golongan, bahkan pribadi. Musik menjadi sesuatu yang tidak lagi naluriah, namun politis-rentan konflik antar pelakunya. Musik menjadi alat, lalu tender alat musik dengan distributor besar, kampanye, lalu korupsi, tenggelam di bui. Terlepas dari itu semua, musik telah membuat setiap orang pada masa kini benar-benar "merdeka" menentukan apa yang diinginkan, menyebarkan kemana saja yang diinginkan, menjual semurah-murahnya, bahkan membagi segratis-gratisnya. (Setiawan, 2016, p. 120)

Musik sudah menjadi seperti "sampah" yang siap dipungut kapan saja. Nilai-nilai sejati dalam musik makin tidak dapat diraba, yang memiliki bakat terbatas dapat naik daun dalam hitungan menit, sedangkan yang tulus dan berdedikasi tidak dihargai, tenggelam dalam kelambu masa.

Synchronize Festival memandang Indonesia dengan jumlah penduduk dua ratusan juta ini, adalah sebuah fakta yang menunjukkan pluralitas itu sendiri. Berbagai macam kesenian tumbuh di tlatah yang dulu disebut nusantara. Tak terkecuali "musik" dalam berbagai jenisnya, dan akan terlalu sulit otak manusia untuk dapat memahami semua jenis musik yang senyata-nyatanya ada dan berkembang di sebuah negara yang telah melewati tujuh kepemimpinan selama tujuh dekade ini.

Secara psikologis, nilai kemanusiaan atas kaitannya dengan hubungan kepekaan antar manusia disebut juga dengan empati. Setiap orang yang memiliki kepekaan (dalam hal apa saja) akan senantiasa memiliki daya kontrol untuk menjaga kualitas hidup dari waktu ke waktu. Apabila manusia menyaksikan tindak kekerasan, tentu memasukkannya sebagai masalah kemanusiaan, maka kekerasan yang terjadi dapat dipahami sebagai akibat dari tidak adanya kepekaan untuk mengormati sesama manusia (Djohan, 2011).

Pendidikan musik sebagai soft skill nantinya akan terus-menerus berkutat pada aspek kepekaan ini (sense) yang parameternya juga akan banyak, bahkan tidak terbatas, antara lain soal perilaku. Keterampilan musik sebagai hasil akhir tidak menjadi soal atas serentetan peristiwa pengalaman bermusik apabila itu didukung oleh pengayaan batin pada tingkat kepekaan atas nilai-nilai kemanusiaan itu. Pendidikan musik selalu berjuang mengayomi nilainilai perilaku dan kepribadian. (Djohan, 2011). Maka dari itu, individualisme dalam pendidikan musik sangat tidak disarankan, meskipun pemahaman nilai-nilai itu harus dicapai secara subyektif (individualitas, yang berbeda dengan individual/individualisme), melalui refleksi, renungan, motivasi orang terdekat. Keputusannya tetap lahir mandiri (Westerlund, 2003). Sementara banyak musisi hebat dilatih untuk menjadi introvert karena harus menghabiskan 
waktu dengan berlatih musik sendirian selama berjam-jam, tidak pernah ada waktu untuk menimba pengalaman kemanusiaan secara langsung. Hal tersebut sangat tidak disarankan, yang agaknya harus dipercayai, bahwa musik dapat senantiasa "digenggam" kemana-mana tanpa sekat ruang dan waktu, untuk digali terus-menerus faedah-faedahnya, sehingga ruang pendidikan dirasa kurang cukup untuk mengoptimalkan nilai-nilai itu. Selalu ada yang tidak dapat diajarkan di ruang-ruang pendidikan yang serba terbatas.

Apresiasi musik melalui pertunjukan musik Synchronize Festival adalah ruang terbuka baru untuk pendidikan musik anak-anak muda. Ruang umum yang membebaskan pengunjungnya untuk mempelajari apa yang ditemuinya. Synchronize Festival yang menyajikan pertunjukan lintas genre, menjadi ruang pendidikan informal baru di kancah pertunjukan musik. Menjadi pelaku musik yang tidak mengenal nilai kemanusiaan ketika pelaku musik hanya berkreasi tanpa berapresiasi.

\section{Kesimpulan}

Pendidikan dan musik tentu dapat dipahami secara masing-masing secara terpisah yang kemudian sebelum disatukan menjadi pendidikan musik. Mencari kemungkinankemungkinan kreatif dengan mengimplementasikan kecerdasan musikal menjadi fundamental sebelum mempelajari konsep dan teori, karena pendidikan musik lebih kepada pengalaman yang dibina terus-menerus. Dalam hal ini Synchronize Festival sebagai festival musik yang menyuguhkan pertunjukan musik lintas genre menjadi ruang belajar baru untuk siapapun yang hadir dalam festival tersebut. Ruang belajar yang bebas untuk mempelajari apapun yang disajikan oleh penyelenggara festival. Synchronize Festival memberikan kemerdekaan dalam belajar di dalam festival yang diadakannya, dari musik lintas genre yang mengedukasi penonton akan musik-musik legendaris hingga musik-musik baru, yang tidak akan bisa didapatkan di lingkungan pendidikan formal.

\section{Referensi}

Anderton, C. (2011). Music festival sponsorship: Between commerce and carnival. Arts Marketing: An International Journal.

Barrett, M. S., \& Bond, N. (2015). Connecting through music: The contribution of a music programme to fostering positive youth development. Research Studies in Music Education, 37(1), 37-54.

Demajors News. (2020a). Synchronize Fest 2020 Tampil di Layar Kaca.

Demajors News. (2020b). Synchronize Fest Inisiasi Gerakan Bersama.

Djohan. (2011). Perilaku Musikal dan Kepribadian Kreatif.

Doğantan-Dack, M. (2012). The art of research in live music performance. Music Performance Research, 5, 34-48.

Finney, J. (2002). Music education as aesthetic education: a rethink. British Journal of Music Education, 19(2), 119-134. https://doi.org/DOI: 10.1017/S0265051702000219

Hakim, A. L. (2015). Seni untuk Semua di Festival Lima Gunung.

Mark, M. L., \& Madura, P. (2013). Contemporary music education. Cengage Learning.

Packer, J., \& Ballantyne, J. (2011). The impact of music festival attendance on young people's psychological and social well-being. Psychology of Music, 39(2), 164-181. 
Purnama, C. (2020). Analisis Strategi Pemasaran Melalui Media Sosial Instagram Pada Kegiatan Syncronize Festival. Podomoro University.

Rahmania, R. A. (2015). Pengaruh Promotion Mix Terhadap Kepuasan Pembelian Tiket Pada Event Indonesia Fashion Week 2015. E-Proceeding of Management, 2(3), 2947-2953.

Septiyan, D. D. (2019). Pengaruh Habitus Dari Selera Musik Terhadap Konsep Diri Penikmatnya. Musikolastika: Jurnal Pertunjukan Dan Pendidikan Musik, 1(2), 101-108.

Setiawan, E. (2016). Musik untuk Kehidupan. Art Music Today Pubisher.

Setiawan, E. (2017). Filosofi Pendidikan Musik: Kritik dan Renungan. Art Music Today Pubisher.

Sinaga, F. S. S. (2020). Musik Trunthung Sebagai Wujud Kearifan Lokal Dalam Konteks Pendidikan Seni. Tonika: Jurnal Penelitian Dan Pengkajian Seni, 3(1), 27-38.

Stone, C. (2009). The British pop music festival phenomenon. International Perspectives of Festivals and Events, 205-224.

Swanwick, K. (2003). A Basic for Music Education. Taylor \& Francis e-Library.

Tarsa, A. (2016). Apresiasi Seni: Imajinasi Dan Kontemplasi Dalam Karya Seni. JPGI (Jurnal Penelitian Guru Indonesia), 1(1).

Westerlund, H. (2003). Bridging experience, action, and culture in music education. SibeliusAkatemia.

Yngvar, K. (2018). Live and Recorded Music Experience in The Digital Millenium. Pop Music, Culture, and Identity. Springer International Publishing. 